\title{
EMBRIOGENESIS PADA TANAMAN TEBU (Saccharum sp.) VARIETAS BULULAWANG DENGAN TEKNIK KULTUR MIKROSPORA
}

\author{
Embryiogenesis In Bululawang Variety Sugarcane (Saccharum sp.) \\ Withmicrospore Culture Technique \\ Septarini Dian Anitasari ${ }^{1}$, Dwi Nur Rikhma Sari ${ }^{1}$, \\ Ida Ayu Astarini ${ }^{2}$, Made Ria Defiani ${ }^{2}$ \\ ${ }^{1}$ Pendidikan Biologi, FP. MIPA, IKIP PGRI Jember. \\ ${ }^{2}$ Jurusan Biologi, FMIPA, Universitas Udayana Bali \\ e-mail: ${ }^{1}$ septarini@ikipjember.ac.id, ${ }^{2}$ dnrs_dinurrisa@yahoo.com, \\ 3ida_astarini@yahoo.com, ${ }^{4}$ defiani_ria@yahoo.com
}

\begin{abstract}
ABSTRAK
Tanaman tebu adalah keluarga poace yang berpotensi menghasilkan nilai ekonomi tinggi karena manfaatnya sebagai produk unggulan dalam menghasilkan gula serta bioetanol yang banyak digunakan oleh masyarakat luas. Untuk itu perlu upaya pemuliaan tanaman yang cepat untuk memenuhi kebutuhan pasar. Teknik kultur mikrospora merupakan aplikasi bioteknologi yang efisien dalam menghasilkan tanaman haploid. Teknik ini belum berhasil diaplikasikan pada tanaman tebu sehingga dalam penelitian ini bertujuan untuk memicu embriogenesis mikrospora tebu dengan aplikasi kultur mikrospora pada varietas bululawang. Metode yang digunakan yaitu dengan stress perlakukan perendaman mannitol $0.3 \mathrm{M}$ sebelum isolasi kultur pada lama perendaman yang berbeda. Analisis data menggunakan uji anova dan uji duncan. Hasil yang diperoleh yaitu Perlakuan stress yang diberikan berhasil memicu embriogenesis mikrospora dengan lama perendaman anther optimum pada 7 hari pada mannitol $0.3 \mathrm{M}$
\end{abstract}

Kata kunci : mikrospora uninukleat, mannitol, tanaman tebu

\begin{abstract}
Sugar cane is a poace family that has the potential to produce high economic value because of its benefits as a superior product in producing sugar and bioethanol which is widely used by the wider community. For this reason, it is necessary to initiate plants that are fast to meet market needs. Microspora culture technique is an efficient application of biotechnology in producing haploid plants. This technique has not been successfully applied to sugarcane plants so that in this study aims to trigger microsporee sugarcane embryogenesis by application of microspore culture in Bululawang variety. The method used is stress treatment of mannitol 0.3M soaking before culture isolation at different soaking times. Data analysis using anova test and duncan test. The results obtained are stress treatments given successfully trigger microspore embryogenesis with optimum anther treatment time at 7 days in mannitol $0.3 \mathrm{M}$
\end{abstract}

Keywords : microspore uninucleate, mannitol, sugarcane 


\section{PENDAHULUAN}

Spesies tebu (Saccharum officinarum Linn.) Adalah famili poace yang komersil sebagai komoditas unggulan seluruh dunia (Fairtrade Foundation, 2013). Tanaman ini banyak dikembangkan di daerah tropis maupun subtropis (Anbanandan dan Eswaran, 2018). Indonesia adalah negara tropis yang cocok dalam pengembangan tebu. Secara umum, tanaman tebu digunakan untuk produksi gula dan bioenergi / bioetanol (Zhao dan Li, 2015).

Kebutuhan gula secara global berpengaruh pada nilai ekonomi dunia. Upaya pemuliaan tanaman tebu terus dikembangkan hingga saat ini. Pemulian tanaman tebu secara konvensional memerlukan waktu yang lama. Pemuliaan ini meliputi proses persilangan individu yang memerlukan waktu lama dan tergantung pada lingkungan. Metode konvensional dapat berpengaruh pada ekspresi dari karakter yang diseleksi sehingga membutuhkan teknologi yang efisien dalam pemulian tanaman tebu. Atas dasar tersebut upaya pengembangan pemuliaan tebu terus dilakukan untuk menghasilkan teknik yang efisien dan menghasilkan varietas baru yang bersifat unggul. Bioteknologi menawarkan teknik pemuliaan tanaman dengan cepat. Salah satu metode yang terbaru dalam pemuliaan tanaman adalah kultur mikrospora.

Teknik ini banyak berhasil dikembangkan pada banyak tanaman holtikultura (Suslow et al., 2002) dan famili poace seperti gandum (Santra et al., 2012). Teknik kultur mikrospora mampu menghasilkan galur murni haploid dan bahkan double-haploids. Pemilihan varietas pada tanaman hasil kultur mikrospora akan lebih mudah karena bersifat homogen dan homozigot sehingga dalam kurun waktu kurang dari setahun atau satu generasi varietas baru dapat diluncurkan (Al-Khayri et al., 2015).

Dalam penelitian ini dikembangkan kultur mikrospora untuk varietas tebu di Indonesia. Tidak ada laporan tentang keberhasilan pada aplikasi teknik kultur mikrospora tanaman tebu. Namun perkembangan teknik kultur mikrospora sudah mulai dikembangkan sejak 40 tahu yang lalu yaitu dimulai dari adanya pengaruh suhu, sukrosa dan 2,4-D dalam isolasi media kultur mikrospora tebu sehingga menghasilkan bentuk procali dan cali diakhir penelitian (Hinchee dan Fitch, 1984). Sampai kurun waktu yang lama perkembangan teknik kultur mikrospora dilanjutkan oleh Suaib et al., (2008) dengan menerapkan metode suhu yang berbeda dan durasi waktu pre treatments sehingga menghasilkan struktur embrio-like. Dengan minimnya informasi tersebut, dalam penelitian ini dikembangan teknik kultur mikrospora dengan perlakuan stres untuk memicu embriogenesis pada tanaman tebu.

\section{METODE PENELITIAN}

Sterilisasi malai dilakukan di luar LAFC (Laminar Air Flow Cabinet) dengan menyemprot malai dengan alkohol $96 \%$ sebelum dimasukkan kedalam LAFC. Tahap selanjutnya yaitupra perlakuan Stress dengan variasi lama penyimpanan menggunakan mannitol strees treatment pada saat inkubasi. Pra perlakuan stres dilakukan dengan memasukkan anther steril ke dalam botol schout steril yang berisi $250 \mathrm{ml}$ larutan mannitol $0,3 \mathrm{M}$. tahap berikutnya yaitu membungkus botol dengan alumunium foil dan 
diinkubasi pada suhu suhu rendah $\left(4^{\circ} \mathrm{C}\right)$ dengan variasi masa perendaman $0,7,14$ dan 21 hari.

Teknik isolasi kultur mikrospora yaitu menumbuk anther yang berisi mikrospora uninukleat sebanyak 300 anther secara perlahan dengan alat penumbuk (mortar dan stamfer) dengan larutan mannitol 0,3M hingga microspore keluar. Setelah ditumbuk kemudian melakukan penyaringan dengan filter $100 \mu \mathrm{m}$. Kemudian mensentrifuge suspensi hasil penyaringan dengan larutan mannitol $0,3 \mathrm{M}$ sebanyak $15 \mathrm{ml}$ dengan sentrifugasi suhu dingin $4^{\circ} \mathrm{C}$ dengan kecepan $750 \mathrm{rpm}$ selama 5 menit. Setelah itu memindahkan pelet yang dihasilkan dalam cawan petri sebanyak $4 \mathrm{ml}$ dengan kepadatan $3 \times 10^{4}$ mikrospora per ml. Kemudian dimasukkan ke dalam media MS pada cawan petri dengan lapisan parafilm. disimpan pada suhu ruang $25^{\circ} \mathrm{C}$ dalam kondisi gelap. Data embrio diamati setelah 60 hari inkubasi kultur mikrospora. Data hasil penelitian dianalisis menggunakan uji anova pada aplikasi SPSS.

\section{HASIL DAN PEMBAHASAN}

Teknik mikrospora dalam penelitian ini berhasil menginduksi mikrospora menjadi embrio. Berdasarkan hasil penelitian yang telah dilakukan, ditemukan bahwa variasi waktu penyimpanan pada perlakuan stress mannitol $0.3 \mathrm{M}$ memberikan pengaruh yang signifikan terhadap jumlah embrio yang dihasilkan dan terdapat pengaruh jumlah embrio yang berbeda nyata secara signifikan pada setiap perlakuan. Jumlah Embrio tertinggi terdapat pada perlakuan T2 yaitu sebesar 711,2 $\pm 8,26^{\mathrm{d}}$. Sehingga dalam penelitian ini perendaman anter selama 7 hari adalah waktu yang optimal bagi mikropora tebu. Data berikutnya diketahui bahwa semakin lama perendaman anther maka embrio yang dihasilkan semakin rendah (Tabel 1).

Tabel 1. Jumlah Embrio setelah isolasi kultur berdasarkan lama waktu pra perlakuan kultur perendaman pada mannitol 0,3M

\begin{tabular}{cc}
\hline T & Jumlah Embrio \\
\hline T1 & $475,2 \pm 4,97^{\mathrm{c}}$ \\
T2 & $711,2 \pm 8,26^{\mathrm{d}}$ \\
T3 & $365,0 \pm 7,65^{\mathrm{b}}$ \\
T4 & $115,6 \pm 5,12^{\mathrm{a}}$ \\
\hline
\end{tabular}

*Ket: T(lama perendaman): T1(0 hari), T2(7hari), T3 (14 hari) dan T4 (21 Hari)

Perkembangan teknik kultur mikrospora dalam penelitian ini berhasil menginduksi mikrospora uninukleat menjadi embrio. embrio yang dihasilkan adalah embrio berbentuk bulat (Globular Embrio) dan berbentuk hati (Heart-shape embrio) (Gambar 1). 


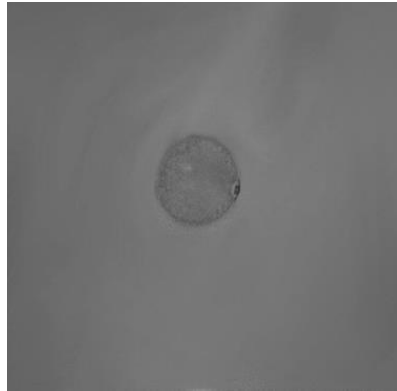

a

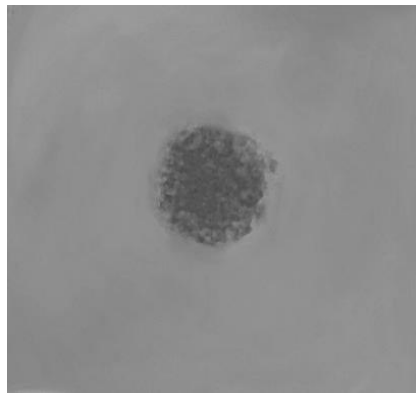

b

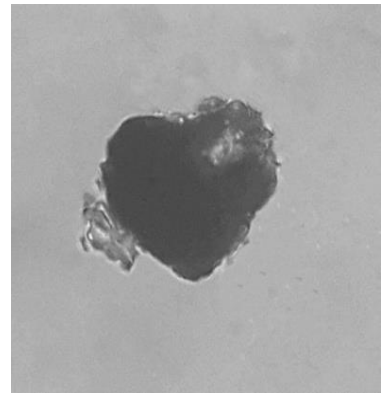

C

Figure 1. Embrigenesis microspore isolation culture for 60 days (a. Uninucleate stage; b. globular embryo; c. heart-shape embryo) pada mikroskop olympus perbesaran 100x

Pemuliaan tanaman tebu dengan teknologi kultur mikrospora di Indonesia belum banyak dikembangkan. sejauh ini belum ada laporan tentang keberhasilan teknik ini pada tebu. sehingga pengembangan teknik ini terus dikembangkan dengan berbagai perlakuan stres. Mikrospora memiliki kemampuan untuk berkembang menjadi tanaman haploid menggunakan kultur in vitro dengan mengubah jalur ke sporofit dengan mencegah perkembangan serbuk sari (gametophytic pathways). Proses sporofitik ini dilakukan dengan perawatan stres pada mikrospora sehingga embriogenesis. Embrio yang dihasilkan benar-benar homozigot sehingga lebih mudah untuk mempelajari pemuliaan tanaman dan pemilihan varietas (Touraev et al., 1997).

Perlakuan stres isolasi mikrospora efektif dalam menghasilkan embrio tebu. Perlakuan stress menggunakan larutan mannitol 0.3 M. Penggunaan larutan mannitol ini sudah banyak diaplikasikan pada tanaman lain. Dalam penelitian menyebutkan bahwa perendaman pada larutan mannitol pada anther sebelum isolasi kultur dapat mengubah ekspresi gen tertentu sehingga mengubah jalur sporofitik ke arah embriogenesis (MunozAmatrian et al., 2006).

Kultur mikrospora merupakan teknik yang unik karena merupakan proses dimana mirospora muda atau fase yang tepat seperti mikrospora uninukleat hingga binukleat memiliki gen yang dapat diekspresikan apabila mendapat stress perlakuan. Gen-gen tersebut diantaranya gen-gen yang mengkode metalicionein yang bersifat asam absisat dan responsif pada cysteine-metalothionein (EcMt), protein arabinogalactan (AGP), smal heat shock protein (HSPs), faktor transkripsi baby boom dan endosperm spesifik protein ZmAE dan ZmAE3 (Maraschin et al., 2005).

Ada beberapa faktor yang dapat mempengaruhi kultur mikrospora seperti genotipe, perawatan stres, media kultur, kepadatan mikrospora dan tahap perkembangan pada mikrospora (Chaar et al., 2014). Proses embriogenesis dalam kultur mikrospora adalah sistem yang unik di mana sel-sel mikrospora diprogram khusus dengan perlakuan stres terhadap jalur embriogenesis. Perlakuan stres dapat berupa variasi suhu inkubasi untuk memicu embriogenesis (Prem et al., 2012).

Induksi embriogenesis dengan aplikasi stress treatmen tidak selalu berhasil pada semua jenis tanaman. Stress treatmen tergantung pada genotip dan varietas tanaman (Shariatpanahi and Ahmadi, 2016). Pernyataan tersebut sejalan dengan penelitian Suaib et al., (2013) yang menyatakan bahwa stres perlakuan suhu pada varietas tebu 
52OC2,52OC4 dan POJ3025, PS58, PS862 menghasilkan struktur seperti embrio setelah satu bulan kultur. Dalam penelitian ini menggunakan varietas yang berbeda yaitu varietas Bululawang. Hasil yang didapat setelah 2 bulan kultur/60 hari menghasilkan embrio globular dan bahkan berkembang menjadi heart-shape embrio. Perlakuan stress mannitol sebelum perlakuan kultur berhasil menginduksi mikrospora uninukleat menjadi embrio. Pra perlakuan stress pada anther sebelum isolasi kultur mikrospora dengan merendam anther dalam larutan $0.3 \mathrm{M}$ manitol selama 7 hari pada $4^{\circ} \mathrm{C}$ merupakan kondisi optimal dalam memicu embriogenesis tanaman tebu. Dalam studi Ayed et al., (2010) teknik ini juga berhasil diaplikasikan pada gandum dan teknik ini efektif dalam memicu embrio mikrospora.

\section{KESIMPULAN}

Kesimpulan dari penelitian ini adalah pengembangan teknik kultur mikrospora dengan perlakuan stres berupa perendaman dalam mannitol 0.3 M selama waktu penyimpanan yang berbeda berhasil diinduksi mikrospora embrio dengan variasi jumlah embrio.

\section{UCAPAN TERIMA KASIH}

Kami berterimakasih kepada KEMENRISTEKDIKTI yang telah mendukung peneletian kerjasama antar perguruan tinggi dengan adanya hibah PKPT 20172018 .

\section{DAFTAR PUSTAKA}

Al-Khayri, J. M., Jain, S. M., \& Johnson, D. V. (Eds.). (2015). Advances In Plant Breeding Strategies: Breeding, Biotechnology And Molecular Tools. Springer International Publishing

Anbanandan, V., \& Eswaran, R. 2018. Association Analysis In Sugarcane (Saccharum officinarum L.). Journal of Pharmacognosy and Phytochemistry 2675-2677

Ayed, O. S., De Buyser, J., Picard, E., Trifa, Y., \& Amara, H. S. (2010). Effect Of Pretreatment On Isolated Microspores Culture Ability In Durum Wheat (Triticum turgidum subsp. durum Desf.). Journal of Plant Breeding and Crop Science, 2(2), 030-038

Chaar, M., Pinker, I., \& Böhme, M. (2014, August). Factors Affecting Microspore Embryogenesis In Petunia. In XXIX International Horticultural Congress on Horticulture : Sustaining Lives, Livelihoods and Landscapes (IHC2014): 1127 (pp. 163-170)

Fairtrade Foundation. 2013. Fairtrade and Sugar. www.fairtrade.org.uk. [13 August 2018 
Maraschin SF, De Priester W, Spaink HP, Wang M (2005) Androgenic Switch: An Example Of Plant Embryogenesis From The Male Gametophyte Perspective. J Exp Bot56: 1711-1726. DOI:10.1093/jxb/eri190

Muñoz-Amatriaín, M., Svensson, J. T., Cas-tillo, A. M., Cistué, L., Close, T. J., \& Valés, M. P. (2006). Transcrip Tome Analysis Of Barley Anthers: Effect Of Mannitol Treatment On Microspore Embryogenesis. Physiologia Plantarum, 127(4), 551-560. Doi: 1399-3054.2006.00729.

Prem, D., Solís, M. T., Bárány, I., Rodríguez Sanz, H., Risueño, M. C., \& Testillano, P. S. (2012). A New Micro-Spore Embryogenesis System Under Low Temperature Which Mimics Zygotic Embryogenesis Initials, Expresses Auxin And Efficiently Regenerates Doubled-Haploid Plants In Brassica napus. BMC Plant Biology, 12(1), 127.

Santra, M., Ankrah, N., Santra, D. K., \& Kidwell, K. K. (2012). An improved wheat microspore culture technique for the production of doubled haploid plants. Crop science, 52(5), 2314-2320. doi:10.2135/cropsci2012.03.0141

Suaib., Woerjono, M., Mirzawan, P dan Indrianto, A. 2008. Kultur Mikrospora: Alternatif, Peluang, Dan Prospek Perbaikan Genetik Pada Populasi Tanaman Tebu (Saccharum spp.). Berkala penelitian agronomi 2: 79-87.

Suslow, T., Thomas, B., \& Bradford, K. (2002). Biotechnology provides new tools for plant breeding. UCANR Publications.

Touraev, A., Vicente, O., \& Heberle-Bors, E. (1997). Initiation of microspore embryogenesis by stress. Trends in Plant Science, 2(8), 297-302.

Zhao, D., \& Li, Y. R. (2015). Climate change and sugarcane production: potential impact and mitigation strategies. International Journal of Agronomy, 2015. 